\title{
Application of Hydrosuction Sediment Removal System (HSRS) on Peaking Ponds
}

\section{H. S. Shrestha}

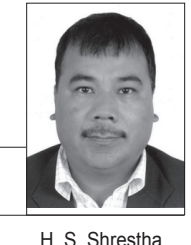

Abstract: The value of the peaking hour energy is very high in Nepal where people are facing more than 16 hours load shedding in a day during the dry period. Currently, the peak load demand is about $90 \%$ higher than the off peak load demand. Therefore, a storage type hydropower project plays a significant role in the Nepalese energy sector and decides the fate of load shedding. However, the Reservoir sedimentation studies in Nepal show that the capacity of the reservoirs has been reduced significantly; hence, preservation of these reservoirs is a vital issue.

The hydrosuction sediment removal system (HSRS) is one of the methods to remove sediment from the reservoirs. A modified double layer suction head of HSRS was used in a field test of HSRS at the Settling Basin of Sunkoshi Small Hydropower Plant (SSHP) and Peaking Pond of the Sunkoshi Hydropower Plant (SHP). This paper presents field test results in the settling basin of SSHP and peaking pond of SHP and applicability of HSRS in the Kulekhani Reservoir and other peaking ponds in Nepal.

Key words: Hydrosuction Sediment Removal System (HSRS), ponds, settling basin, reservoir, Nepal

\section{Introduction}

$\mathbf{H}$ ydrosuction Sediment Removal System (HSRS) is one of the methods of sediment flushing that uses the hydraulic head available at the dam as energy to remove sediment as shown in Figure 1. It consists of a pipeline and valves to control the flow. The pipeline entrance is placed upstream at a location where sediment capture or removal is desired in a reservoir or pond. The pipeline extends downstream either over the dam or through low-level outlets to downstream.

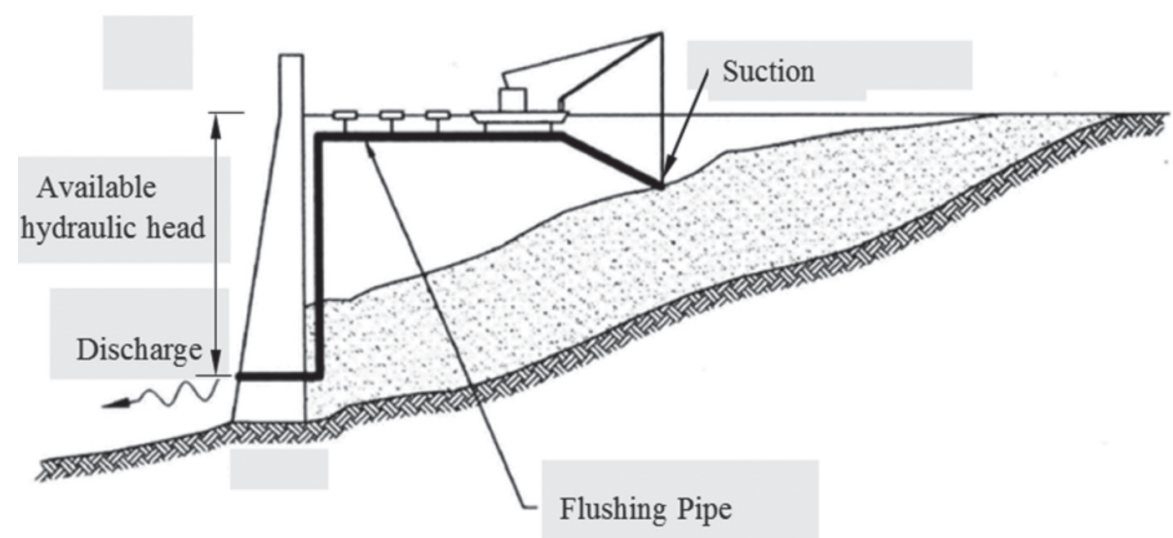

The People's Republic of China to date has the most experience with hydrosuction dredging. The Chinese have used either siphon or bottom withdrawal modes in 10 reservoirs since 1975. They further state that Shahriar Eftekharzadeh was responsible for beginning the investigation of hydrosuction sediment removal in the United States. Hotchkiss and Huang (1995) also developed the "Dustpan" inlet for HSRS and tested it at the Lake Atkinson on the Elkhorn River in Nebraska during the summer of 1993. Jacobsen (1997) developed the Slotted Pipe Sediment Sluicer (SPSS) and Saxophone Sediment Sluicer (SSS) in 1993 during his PhD study. According to Jacobsen (2006), a hydrosuction removal system was installed in the Malana Hydro Station (86 MW run-ofriver plant) in the Kullu District of Himachal Pradesh, India in May 2005 for the removal of sediment. The Inverted Cone Sediment Sluicer (ICSS) type or the funnel shape suction head was developed in India

Figure 1. Hydrosuction Sediment Removal System (HSRS).

A double layer suction head of HSRS has been modified to minimize problems related to clogging of the sediment flushing pipe and water jetting arrangement incorporated to break up the consolidated sediment deposit.

\section{Previous Studies}

Hotchkiss and Huang (1995) reported several case histories of application of HSRS. HSRS dredging was first performed in the Djidiouia Reservoir in Algeria from 1892 to 1894 . According to them, the "hydroaspirator" method for removing sediment had been conceived in France about 100 years ago but was not used extensively. and was successfully used for sediment removal at the Salal Hydropower Project in India (Belete 2007). The Double Layer Sediment Sluicer (DLSS) was developed by Kiflom Belete during his PhD study. Belete (2007) reported that the performance of the DLSS was found to be higher compared to the SSS and the ICSS. Further, he concluded that the DLSS suction head was found more promising for use in the prototype reservoirs where deposited sediment is dominated by more cohesive and consolidated materials.

\section{The Modified Double Layer Sediment Sluicer (MDLSS)}

The Double Layer Sediment Sluicer (DLSS) is slightly modified with the water jetting arrangement to break up 
the consolidated sediment deposit. The drawing of the modified DLSS is shown in Figure 2.

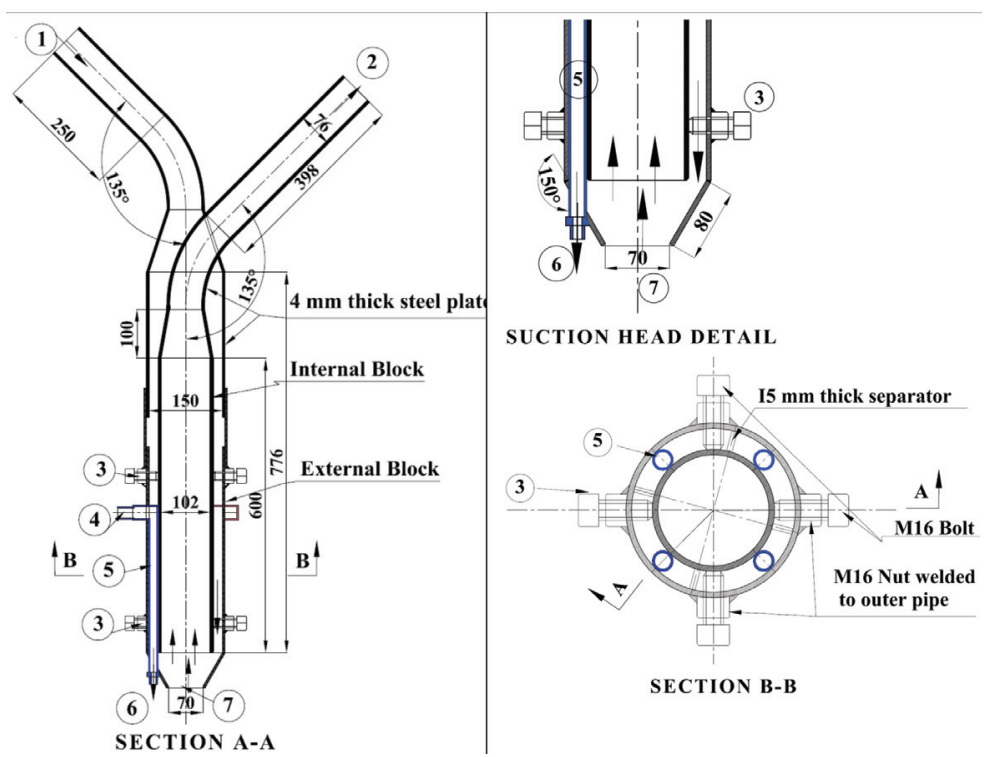

Figure 2. Suction Head of Modified DLSS

In the Figure; 1) Inlet for extra water, 2) Outlet, 3) Bolt to adjust the External Block, 4) 1" Nipple to connect the pressure pipe, 5) Pressure pipe for water jetting, 6) Nozzle for water jetting, 7) Inlet of the Suction Head.

The Inlet (1) supplies clear water into the main suction head through the space between the external pipe and main suction pipe. Clear water is used for self-clearing in case there is excess suction of sediment or the mouth is stacked inside the sediment deposit. The amount of clear water can be controlled with a valve located at the inlet pipe and by adjusting the external block and main suction pipe with bolts (3). Four nozzles (6) are mounted at the inlet of the suction head for water jets to break up the consolidated sediments (if required). The diameter of the water jet nozzles is $5 \mathrm{~mm}$ and connected with $25 \mathrm{~mm}$ (1-inch) pipe (5). A high-pressure pump is used to supply clean water and is mounted with a high velocity water jet.

\section{Field Experiment Location}

Field test with the Modified Double Layer Sediment Sluicer (MDLSS) was performed at the Settling Basin of the Sunkoshi Small Hydropower Plant and at the Peaking Pond of the Sunkoshi Hydropower Plant from 19 to 24 July 2009. The Sunkoshi Small Hydropower Plant is located in the Sunkoshi Khola of Sindhupalchok District of Nepal. The Project is run-of-river type, which diverts a design flow of $2.7 \mathrm{~m}^{3} / \mathrm{s}$ through $2.6 \mathrm{~km}$ long glass reinforced pipes (GRP) to the powerhouse. The water diverted from the river first reaches the settling basin through an approach canal and enters into the headrace system through the forebay. Utilizing a rated head of $117.5 \mathrm{~m}$, the project generates 2.5 MW of power. The settling basin consists of two chambers with $4.5 \mathrm{~m}$ wide and $45 \mathrm{~m}$ long settling zone.

The Sunkoshi Hydropower Station is located about seven kilometers downstream of the Sunkoshi Small Hydropower Plant (2.5 MW). It is a peaking run of the river type with an installed capacity of $10.05 \mathrm{MW}$ and consists of the headworks area, the canal, peaking pond and the powerhouse area.

\section{Experimental Setup}

The experimental setup for field experiments consist of the suction head or intake, pipes, valves, pump and a raft. The Modified Double Layer Sediment Sluicer (MDLSS) was used as the intake for the system. Forty meter long and $75 \mathrm{~mm}$ (3 inch) diameter flexible corrugated HDP (High Density Polyethylene) pipes were used for the sediment transport and to feed clear extra water for self-cleaning in case there is excess suction of sediment or the mouth is stacked inside the sediment deposit. The sediment transport pipe was connected at the outlet of the suction head and equipped with a check valve (to stop water flow towards the intake during priming) near the connection and a ball valve at the outlet of the pipe. A $2 \mathrm{~kW}$ centrifugal pump was used for priming and water jetting. A locally produced raft made of drums was used for moving the suction head. The experimental setup in the settling basin of the Sunkoshi Small Hydropower Plant and in the peaking pond of the Sunkoshi Power Plant is shown in Figure 3 and Figure 4.

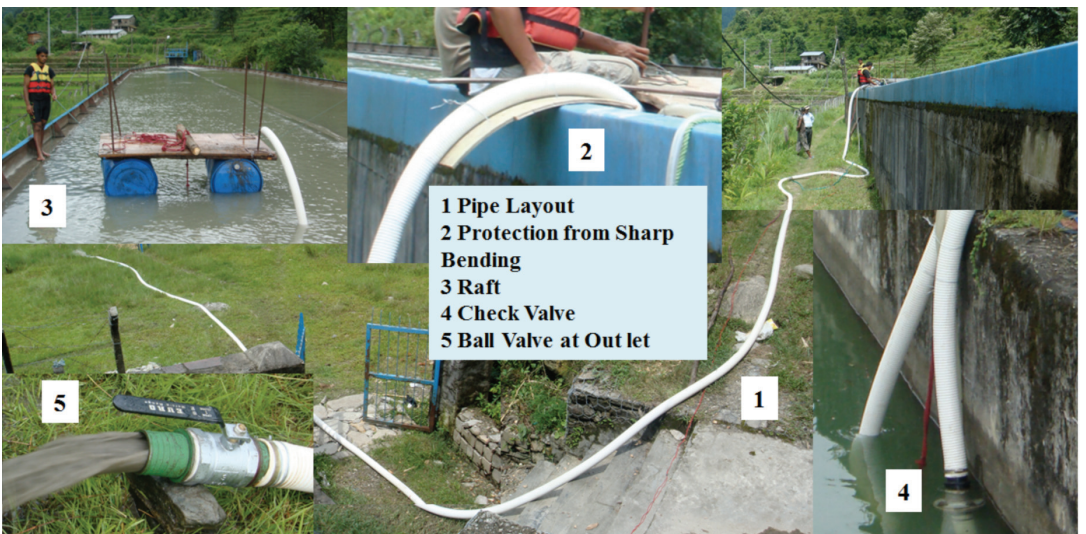

Figure 3. Experimental Setup in Settling Basin of Sunkoshi Small Hydropower Plant.

A pipe was laid over the side wall (0.4 $\mathrm{m}$ above water level) of the settling basin in the Sunkoshi Hydropower (SHP) Plant and over the flushing gate area $(1.2 \mathrm{~m}$ above water level) in the peaking pond of the Sunkoshi Hydropower Plant. The outlet of the pipe was kept near the sediment flushing canal in the settling basin of the Sunkoshi Small Hydropower Plant and in the stilling basin of the spillway of the forebay in the Sunkoshi Hydropower Plant. 


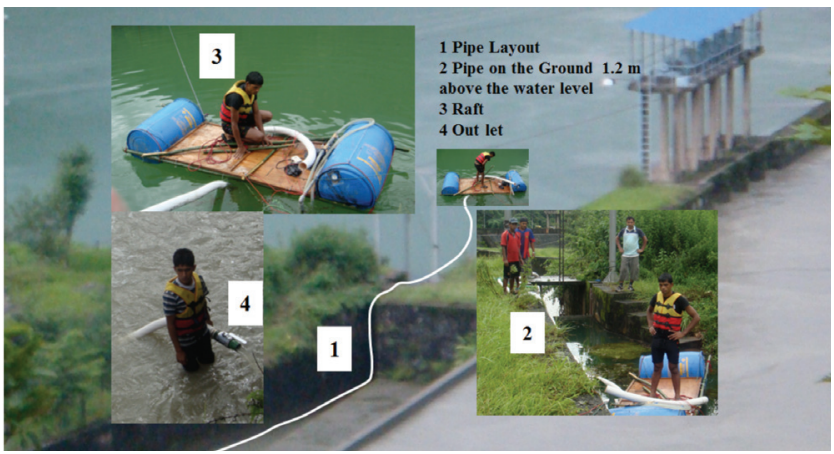

Figure 4. Experimental Setup in the Peaking Pond of the Sunkoshi Hydropower Plant.

\section{Sediment Removal Operation}

Since the pipe layout was above water level, priming of the pipe system was done by pumping water from the settling basin and peaking pond. During priming, the ball valve at the outlet was closed; air was released from the system through the air release valve located at the highest point of the pipe. The check valve stopped the water flow towards the intake during priming. After the pipe was successfully filled with water, the air release valve was closed; the downstream valve was opened and suction was developed and transportation (sluicing) of sediment mixed with water took place. An area with sediment deposits consisting more than one metre thickness was selected for this experiment. The sediment deposit level was measured manually using a $25 \mathrm{~mm}$ (1-inch) square steel pipe having $15 \mathrm{~cm} \mathrm{x} 15 \mathrm{~cm}$ flat plate at the end. Measurement was done before and after sluicing the sediment deposit as shown in Figure 5 . The suction head (inlet) was slowly lowered to the bed and moved to different locations after the concentration of sediment mixture in the outflow pipe was reduced. All inlet movements were done manually. Sediment mixed with water was collected in a 200 liter drum to measure the discharge as shown in Figure 5.
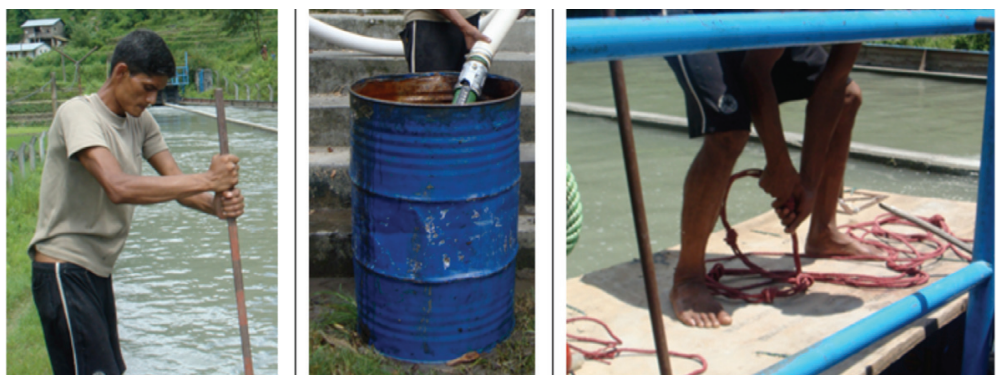

Figure 5. Measurement of Sediment Deposition Level, Discharge and Relocation of Suction Head.
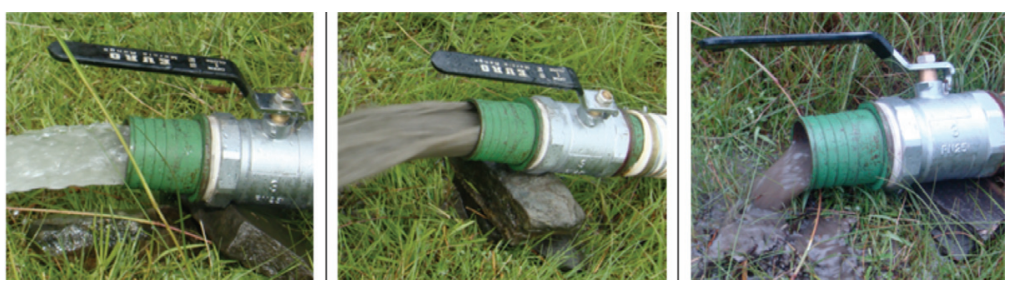

Figure 6. Flow at the Outlet after Priming, Normal and Clogged Flow.
When the suction head and transportation pipes were blocked (Figure 6), they were cleared by lifting the suction head up from the sediment deposit. This was done by drawing clear water from the pond and injecting it into the pipe using the pump. If it did not work, the suction head was brought to the water surface to check if it was blocked by debris (Figure 7) and, after removal of the blocking material, the work was resumed again.

Sluicing was performed by both supplying and not supplying extra clear water at different opening widths of the inlet (gap between the internal and external pipes at the suction head inlet). The available head for sediment sluicing in the settling basin of the Sunkoshi Small Hydropower Plant was $3.8 \mathrm{~m}$ for downstream and $3.0 \mathrm{~m}$ for upstream and $3.1 \mathrm{~m}$ in the peaking pond of the Sunkoshi Hydropower Plant.
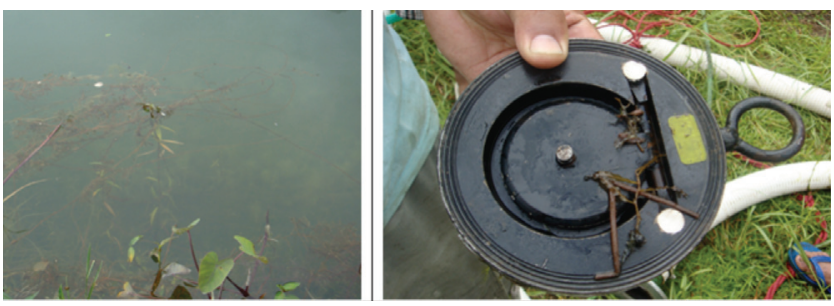

Figure 7. Dense Weed Growth in Peaking Pond and Debris Catching on the Valve Plate.

The peaking pond of the Sunkoshi Hydropower Plant is utilized during the dry (winter) season when very low sediment concentration exists in the river. During the wet (monsoon) season, the inlet gates of the peaking ponds are closed to stop the access of sediment-loaded water. Since the peaking pond is located just upstream of the forebay and is only used during the dry season, the annual sediment deposition rate in the peaking pond is low. Sediment was not flushed for a long time and, therefore, sediment was accumulated year after year. About 20\% volume of the peaking pond was already filled with sediment. The sediment deposit was found to be highly consolidated with dense weed growth (Figure 7). Hence, to evaluate and improve the performance of the hydrosuction sediment removal, a test was carried out with and without the water jetting system. The water jet was used to disintegrate the consolidated sediment deposit. The jets through the nozzles were directed into the sediment deposit to break its cohesiveness so that it was easy to transport through the pipeline system.

\section{Operational Difficulties}

The following difficulties were faced during the field experiment:

- Pipeline clogging occurred when extra clear water was not supplied to the suction head. Once the transportation 
pipe was clogged, clearing the sediment from the pipe was difficult.

- It was challenging to know if the suction head was positioned vertically or not. At the beginning, the verticality of the suction head was checked with the water depth and length of the rope dropped. However, after relocation of the suction head, it was quite difficult to know its exact location. The location of the suction head was detected by water jetting.

\section{Experimental Results}

There was no exact measurement of removed sediment, as it was difficult to take measurements. On

\begin{tabular}{|c|c|c|c|c|c|c|}
\hline S. No. & $\begin{array}{c}\text { Sampling } \\
\text { Date }\end{array}$ & $\begin{array}{c}\text { Opening } \\
\text { for Clear } \\
\text { Water }\end{array}$ & $\begin{array}{c}\text { Total } \\
\text { Concentration } \\
\text { (PPM) }\end{array}$ & $\begin{array}{c}\text { Head } \\
\text { (m) }\end{array}$ & $\begin{array}{c}\text { Discharge } \\
\text { (Ips) }\end{array}$ & $\begin{array}{c}\text { Velocity } \\
\text { (m/s) }\end{array}$ \\
\hline 1 & 20 July 2009 & Closed & 102,600 & 4.5 & 6.06 & 1.37 \\
\hline 2 & 20 July 2009 & Closed & 98,100 & 4.5 & 6.25 & 1.42 \\
\hline 3 & 21 July 2009 & Closed & 105,000 & 4.5 & 6.06 & 1.37 \\
\hline 4 & 21 July 2009 & $2 \mathrm{~cm}$ & 92,000 & 4.5 & 6.45 & 1.46 \\
\hline 5 & 21 July 2009 & $2 \mathrm{~cm}$ & 83,100 & 4.5 & 6.67 & 1.51 \\
\hline 6 & 22 July 2009 & $2 \mathrm{~cm}$ & 60,900 & 3.75 & 5.56 & 1.26 \\
\hline 7 & 22 July 2009 & $4 \mathrm{~cm}$ & 55,800 & 3.75 & 5.71 & 1.29 \\
\hline 8 & 23 July 2009 & $4 \mathrm{~cm}$ & 38,500 & 3.75 & 6.06 & 1.37 \\
\hline 9 & 23 July 2009 & $4 \mathrm{~cm}$ & 44,700 & 3.75 & 5.88 & 1.33 \\
\hline
\end{tabular}

Table 1. Summary of Sediment Concentration Removed from the Settling Basin of the Sunkoshi Small Hydropower Plant.

\begin{tabular}{|c|c|c|c|c|c|}
\hline S.No. & $\begin{array}{c}\text { Sampling } \\
\text { Date }\end{array}$ & $\begin{array}{c}\text { Water } \\
\text { Jetting }\end{array}$ & $\begin{array}{c}\text { Total Concentration } \\
\text { (PPM) }\end{array}$ & $\begin{array}{c}\text { Discharge } \\
\text { (Ips) }\end{array}$ & $\begin{array}{c}\text { Velocity } \\
\text { (m/s) }\end{array}$ \\
\hline 1 & 24 July 2009 & No & 3,900 & 5.41 & 1.22 \\
\hline 2 & 24 July 2009 & No & 4,700 & 5.41 & 1.22 \\
\hline 3 & 24 July 2009 & No & 12,300 & 5.56 & 1.26 \\
\hline 4 & 24 July 2009 & Yes & 23,600 & 5.71 & 1.29 \\
\hline 5 & 24 July 2009 & Yes & 24,700 & 5.71 & 1.29 \\
\hline 6 & 24 July 2009 & Yes & 28,400 & 5.88 & 1.33 \\
\hline 7 & 22 July 2009 & $4 \mathrm{~cm}$ & 55,800 & 3.75 & 5.71 \\
\hline 8 & 23 July 2009 & $4 \mathrm{~cm}$ & 38,500 & 3.75 & 6.06 \\
\hline 9 & 23 July 2009 & $4 \mathrm{~cm}$ & 44,700 & 3.75 & 5.88 \\
\hline
\end{tabular}

Table 2. Summary of Sediment Concentration Removed from the Peaking Pond of the Sunkoshi Hydropower Plant.

the other hand, the performance of the sluicing system was assessed based on sample analysis in the laboratory. During the field experiment, samples were collected in bottles for sediment concentration calculation. The sediment concentrations removed from the settling basin and from the peaking pond are tabulated in Table 1 and Table 2 respectively.

As sediment concentration in the river was high during the field experiment, the frequency of sediment filling in the settling basin was high and sediment was flushed after every two days. Therefore, the sediment in the settling basin was not consolidated and was easy to flush without water jetting. The highest sediment concentration was recorded up to 105,000 PPM when performed without feeding clear water but the pipeline was clogged two times in a period of 12 hours. There was no any clogging after clear water was fed but the sediment concentration dropped to about 38,500 PPM.

The sediment deposit in the peaking pond of the Sunkoshi Hydropower Plant was highly consolidated. Hence, the test was carried out with and without water jetting system and without feeding clear water. The concentrations found using the suction head with and without water jetting were recorded as maximum of 28,400 PPM and minimum of 3,908 PPM respectively.

\section{Discussion}

During the experiment, pipeline clogging occurred two times within 12 hours of operation when clear water was not supplied to the suction head. This may be due to the fact that the sediment concentration was high in the flow. This shows that it is important to supply some clear water to balance the suction capacity of the suction head and transportation capacity of the pipe. This may help to avoid deposition by adding as much clear water to the pipeline as it can transport with optimum concentration of sediment. No clogging was recorded after feeding clear water into the system, but it is obvious that the sediment concentration was reduced considerably. When the openings at the intake between the outer and inner blocks were kept at $2 \mathrm{~cm}$, the concentration varied from 60,700 to 92,000 PPM. Similarly, when the opening was $4 \mathrm{~cm}$, the concentration came down to 44,700 and 55,800 PPM. It shows that clogging could be avoided by feeding clear water into the pipeline through the suction head. However, the gap between the outer and inner pipe of the suction head need to be adjusted to admit the required water for optimum sediment mixed water transportation capacity.

Sediment deposit in the peaking pond was highly consolidated. The hydrosuction system could sluice only 3,900 to 12,300 PPM. However, it was possible to increase the performance up to 28,400 PPM by applying the water jetting system. The water jetting was performed only with a $2 \mathrm{~kW}$ centrifugal pump, which is not that significant. This demonstrates that higher sediment concentration could be achieved by using higher capacity water jetting pumps. 


\section{Possibility of Application of HSRS in Peaking Ponds}

According to Kayastha (2010), the maloperation of the Middle Marsyangdi reservoir during June-July 2009 has resulted in high sedimentation in the live storage of the reservoir. Sediment deposition in the Middle Marsyangdi reservoir after the monsoon of 2009 is shown in Figure 8.

Similarly, the Kali Gandaki 'A' Hydropower Plant reservoir was also significantly affected by reservoir sedimentation. Figure 14 shows the sediment deposition in the reservoir and in the forebay of the plant.
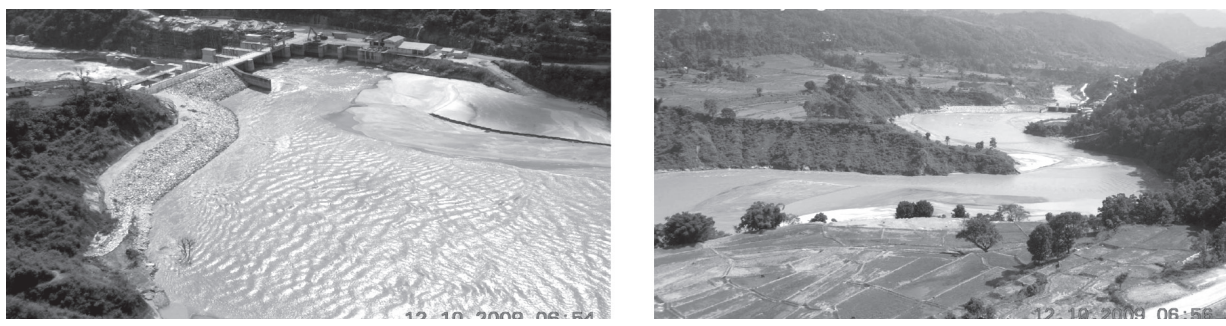

Figure 8. Sediment Deposition in Middle Marsyangdi Reservoir (Kayastha 2010).

As seen in Figures 8 and 9, excessive sedimentation is one of the major challenges for sustainable hydropower operation in the Himalayan region.

The Kali Gandaki 'A' Hydropower Plant is the biggest hydropower plant in Nepal and has an installed capacity of 144 MW. On the other hand, the Middle Marsyangdi
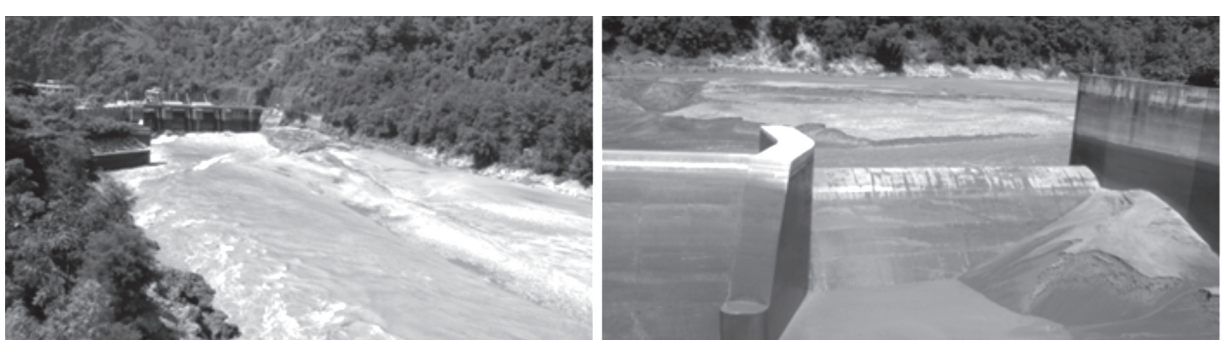

Figure 9. Sediment Deposition in Reservoir and Fore Bay of the Kali Gandaki 'A' Reservoir.

Hydropower Plant has an installed of $70 \mathrm{MW}$ and was commissioned in December 2008. At present, both the Kali Gandaki 'A' and Middle Marsyangdi Hydropower Plants supply almost $1 / 3$ rd of the total hydropower energy produced in Nepal. The sustainability of these reservoirs is vital for the smooth supply of energy during the monsoon period.

The Middle Marsyangdi reservoir has lost about 3.52 million $\mathrm{m}^{3}$ capacity during two years of operation. It is about $65 \%$ of the original capacity of the reservoir. The

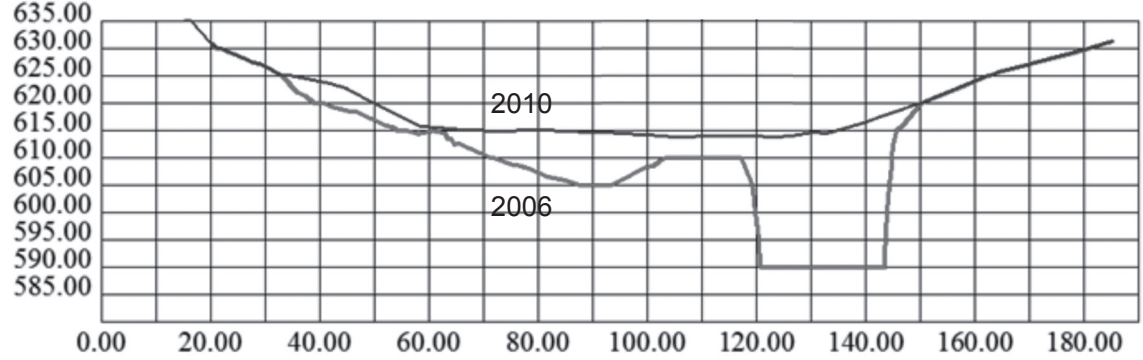

Figure 10. Cross Section about $70 \mathrm{~m}$ Upstrean of Dam. Maximum Operating Level of Reservoir is 326 masl. sediment deposition pattern upstream of the intake area is shown in Figure 12 and the cross section profile at about $70 \mathrm{~m}$ upstream of the dam is shown in Figure 16. The deposition pattern indicates that the sediment deposition will be extended towards the intake area in the near future if no control measures are implemented. Intake capacity will be significantly reduced once sediment deposition reaches up to the intake.

The extension of the sediment deposit towards the intake and falling of boulder from riprap during the reservoir flushing at minimum reservoir level can be prevented by building up a waterway along the left bank by shifting the sediment deposit from the intake area to the left bank. The modified hydrosuction sluicing system can be used for shifting the sediment deposit from the right bank to the left bank.

An experiment shows that this system can be applied to remove the sediment from the head pond. But PSD is an extremely important issue for removing sediments so before applying this system a proper knowledge of practice size distribution of deposited sediment is necessary. sediment removal from the reservoirs and peaking ponds. The sediments may be removed only during the monsoon season when there is excess water, which will prevent production loss from the plants.

The field test study demonstrated that the performance of hydrosuction sediment removal can be increased if hydrosuction is combined with water jetting to break the consolidated sediment deposits.

The efficiency and performance of the system can be improved if the gap between the internal and external pipe of the suction head is adjusted to supply the optimum amount of clear water, which helps to avoid clogging during sediment transportation through the pipeline.

The modified hydrosuction sluicing system can also be used to shift the deposited sediment from one area to another area 
(for example from the right bank to the left bank), which may prevent against sediment deposition in the intake or other relevant areas.

Hari Shankar Shrestha, a Hydropower Engineer, holds M.Sc. in Hydropower Development and Hydraulics. He has more than 19 years experience in hydropower project study, planning and development. He was involved in the Khimti (6o MW), Sunkoshi Small Hydropower Project (2.5 MW), Khudi (4 MW) and Pheme Small Hydropower Project (1 MW) which are in operation. He had also been involved in the detailed design and feasibility of different hydropower projects. At present, he is pursuing $\mathrm{PhD}$ at the Norwegian University of Science and Technology, Trondheim, Norway.

Worked in:

- Institute of Engineering, Pulchowk Campus as Lecturer

- Butwal Power Company as Design Team Leader

- Sanima Hydropower Pvt. Ltd. as Design Team Leader and Chief Engineer

- Sanima Hydro and Engineering as Managing Director

Corresponding address: hari.shrestha@ntnu.no

\section{References}

Belete, K., 2007, "Sedimentation and Sediment Handling at Dams in Tekeze River Basin, Ethiopia”, Doctoral thesis. Trondheim: Norwegian University of Science and Technology

GoN, 2008, Committee Report for Solving the Load Shedding Problem, Kathmandu: Ministry of Water Resources, Government of Nepal

Hotchkiss R.H. and Huang X., 1995. Hydrosuction Sediment Removal Systems (HSRS): Principles and field test. Journal of Hydraulic Engineering, Vol. 121 no. 6 pp 479-489

Jacobsen, T., 1996, Removal of Sediments from Reservoirs, Proceedings of the International Conference on Reservoir Sedimentation Volume 2: pp 801-818

Jacobsen, T., 1997, "Sediment Problems in Reservoirs - Control of Sediment Deposits". Doctoral thesis. Trondheim: Norwegian University of Science and Technology

Jacobsen, T., 2006, Sediment Removal at the Malana reservoir, India, Hydropower and Dams, Issue 1: pp 74-77

Kayastha G. P., 2010, Sediment study and Management in Middle Marsyangdi Hydropower Plant, Sediment Workshop 2010, Kathmandu, Hydro Lab and ICH

Sangraula D. P., 2005, Sedimentation and Sustainability of Kulekhani Reservoir, A Himalayan Case, Doctoral Thesis, Trondheim: Norwegian University of Science and Technology

"Dedicated to improve liveliboods of communities, particularly the poor, by collective utilization of renewable resources, while ensuring due care for the environment"

\section{INNOVATIVE PROJECTS:}

1. Pro Poor Hydropower Pilot Project

- Pro Poor Hydropower is a concept by which the rural poor of Nepal are facilitated into the profitable ownership of their water resources.

2. Bio Fuels Project

- The Bio fuels project aims to help poor villagers in Okhaldhunga district develop alternative ways of creating a livelihood by harvesting inedible oil bearing seeds particularly Jatropha seeds.

3. Pico Hydro Promotion Project

- Enhancing livelihoods and raising the standard of living of the rural poor through provision of electricity achieved through the utilization of their natural resource by robust and sustainable low-head pico hydro technology.

For further detail information, please contact:

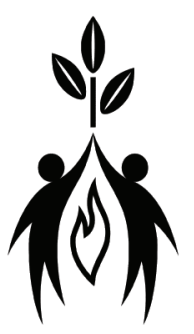

\section{People, Energy \& Environment Development} Association (PEEDA)

Bhanimandal, Ekantakuna, Lalitpur

P.O. Box 8975, EPC 2157, Kathmandu, Nepal

Phone: + 977-1-5540792, 5530337

Web: www.peeda.net; E-mail: mail@peeda.net 